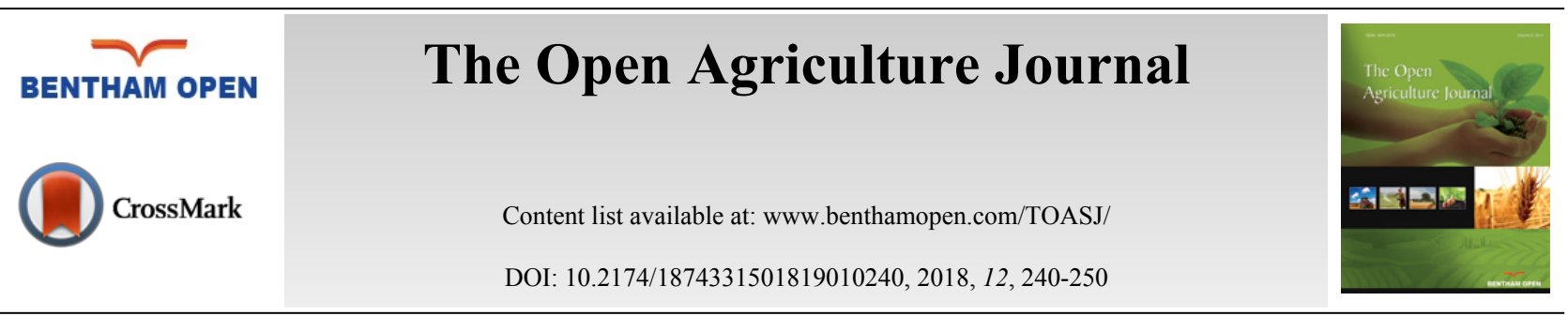

REVIEW ARTICLE

\title{
Challenges and Opportunities of Genetically Modified Crops Production; Future Perspectives in Ethiopia, Review
}

\author{
Kiros Gebretsadik ${ }^{1, *}$ and Ashenafi Kiflu ${ }^{2}$ \\ ${ }^{1}$ Aksum University, Department of Plant Science, P.O.Box 314 Shire, Ethiopia \\ ${ }^{2}$ Aksum University, Department of Biotechnology, P.O.Box 1010 Aksum, Ethiopia
}

Received: May 22, 2018

Revised: September 27, 2018

Accepted: October 31, 2018

\begin{abstract}
:
Introduction:

Genetically modified (GM) crop species were proven to be a solution for the increasing food consumption in many countries. The cultivation of transgenic plants is increasing from time to time. In 2017 alone, 27 different genetically modified (GM) crop species were produced in 40 countries.
\end{abstract}

\section{Explanation:}

Biotechnology is revolutionizing science, promising to solve hunger, malnutrition and production demands of industrial raw materials from plants. However, there are biosafety concerns that GM crops may have unintended and hazardous impacts on living organisms well-being and environment both on target and non-target organisms. To tackle such potential problems many countries are implementing international as well as national biosafety regulations. America, Brazil, Belgium, China and India are among the top GM crop users in the world, whereas Egypt, Sudan, South Africa and Burkina Faso are leading GM crop producers in Africa. Ethiopia has also developed its own policy and biosafety regulations for biotechnology products.

\section{Conclusion:}

The Ethiopian government has given due attention to GM crops as a tool for the transformation of agricultural productivity and quality. Before a couple of years, Bt cotton (cotton containing toxic protein from Bacillus thuringiensis) has been introduced to Ethiopia and is expected to bring fundamental change in the production of fibers for the textile industries and also will have crucial consequence to the forthcoming use of the modern biotechnological Science in the country. The introduction of Bt cotton is a typical example worth mentioning here which shows a relative flexibility of the current Ethiopian biosafety regulation. This paper reviews the possible challenges and opportunities of using GM crops in Ethiopia.

Keywords: Crops, Challenges, Ethiopia, Genetically Modified, Opportunities, Biotechnology.

\section{INTRODUCTION}

The ever-increasing human population which is expected to reach 9.8 billion by 2050 [1] and the new concerns connected with the global climate variation, \& increasing demand to agricultural raw materials for industries will place enormous influence on natural resources, including water and arable land for crop production [1]. Lack of cultivable area, increasing input cost, limited lifespan of irrigation structures, fresh products postharvest losses, weeds, insect pests and diseases are most of the main challenges that are influencing world food production $[2,3]$.

About half of the world's population will live in India, Nigeria, Democratic Republic of Congo, Pakistan, Ethiopia, the United Republic of Tanzania, the United States of America, Uganda and Indonesia (arranged due to their role

\footnotetext{
* Address correspondence to this author at the Aksum University, Department of Plant Science, P.O.Box 314 Shire, Ethiopia; Tel: +251 914186296; E-mail: kiros27@yahoo.com
} 
increasing population contribution growth) [1] within the next 32 years. According to the same report, African population is swiftly increasing representing $17 \%$ of the world's population which is 1.284 billion people from the total 7.550 billion world population in 2017.

Africa is the only continent where food production per capita is falling and where hunger and malnutrition afflict at least one in three people [4]. The current crop production management practices in Africa are unable to produce satisfactory quantities yield to feed the over increasing population [5]. Reports indicated that, the population of Ethiopia was 18, 128,000 in 1950 and has grown to 104, 957,000 in 2017, and is expected to escalate to 139, 620,000 and 190, 870,000 in 2030 and 2050, respectively [1]. Feeding more than 9 billion people after 30 years will be one of the great challenge to human kind, may be the most intimidating encounters facing to world during the remaining years of this $21^{\text {st }}$ century [6] and hence to feed this rapidly growing population of the world, agricultural yields need to be increased. For example, cereal production needs to increase from 2068 million tons in 2005 to 3009 million tons in 2050, which is about $45.5 \%$ increase [7]. Supposing the $80 \%$ of this incensement would be obtained from crop yield which indicates that crop yields must improve by $35.0 \%$ in the coming 32 years. This translates into or is equivalent to an annual growth rate of $0.9 \%[8]$.

Expanding use of arable land, irrigation practices, application of chemical inputs such as fertilizers, herbicides and pesticides and other agricultural practices, played very important role to the increase of crop yield during the Green Revolution in the $20^{\text {th }}$ century. However, it was criticized that the opportunities were overcome by undesired characteristics which negatively affected natural resources including the environment, land degradation, salinization of irrigated areas, over-extraction of groundwater, buildup of chemical resistant pest and diseases, declining of beneficial plants and animals' biodiversity, the release of greenhouse gases and nitrate pollution of water bodies [9]. Increasing world population, climate change, and insufficient poverty interference agendas have eroded many of the gains of the Green Revolution [10].

Agricultural biotechnology, defined as any scientific application using biological schemes, living things or derivatives to create or modify for definite role in agriculture [11, 12]. It can bring great impact on agricultural productivities, qualities and sustainability [8]. Biotechnological applications vary from low-tech approaches, for example like artificial insemination, fermentation techniques and bio-fertilizers, to high-tech tactics and advanced DNA-based techniques, such as genetically modified organisms [8].

Agro-bacterium mediated genetic engineering methods were established in the late 1980s which implied the transfer of gene material effectively to the nuclear genomes of tomato plant [13]. In Africa, although the adoption of genetic engineering was comparatively poor, visible progress has been observed in few countries like South Africa, Egypt, Sudan, Kenya and Burkina Faso where some farmers have started rising Genetically Modified (GM) crops including Bt cotton (cotton containing toxic protein from a bacteria known as Bacillus thuringiensis) and Bt maize (maize containing toxic protein from Bacillus thuringiensis) which is genetically engineered bacterium that produces different toxins each harmful to diverse insects and pathogens [14].

In Ethiopia, there is great expansion of textile manufacturing industries all over the country starting from the establishment of industrial parks. Furthermore, the expansion of agricultural industrial parks is anticipated to drive to increase the demand of cotton supply and production in Ethiopia [15]. Ethiopian cotton productivity is deficient to meet the increasing demand of the textile industries and hence the country is importing cotton (including Bt cotton) from various international suppliers [16]. Government led outreach, and comparatively low labor cost, low electricity costs, undeserved governmental support, loan and appreciable tax exemption has already attracted a number of Chinese, Turkish, Indian, Indonesian and other foreign companies opening their firms in Ethiopia in recent years [16]. To meet the cotton demand, Ethiopia has planned to begin commercialization of Bt cotton following the implementation of a decree that granted research rights both in the laboratories and farm land. Hence, confined experimental trials are underway and commercialization of Bt cotton is expected within the next couple of years [15, 17]. National Agricultural Biotechnology Research Center is established and a total of 68 studies are undergoing in four centers [12].

A major and polarizing debates about Genetically Modified Organisms (GMOs) have been a major issues starting from 1990s [8]. These debates revolve about the possible effect on human being and animal health's, the environment, plant biodiversity and the world food chain. It is belied that crop genetic engineering can aid in most conditions on food security as it improves crop productivity and quality [8]. However, genetic modification of crop plants raises worries on potential hazards to living things and environment where the probable challenges and opportunities need to be cautiously assessed on a case-by-case base [18]. The advance of a country-based controlling framework requests to 
include consideration of current biosafety contexts and functionality and the implications as well as responsibilities of the then Convention of Biological Diversity (CBD) and Cartagena procedure on biosafety [19].

Agrarian biotechnology the potential benefits as well as risks, is a widely discussed issue in most countries, where views people vary significantly and sometimes are relatively different [20]. Risk assessment of possible toxicity and allergenic effects on health of human or animals should be studied [19]. Moreover, the influence on gene flow inside species and to wild families, invasiveness as well as not possible vector for plant disease need to be conducted before the introduction of genetically modified crop.

It was suggested that the proved benefits of genetically modified food products apparently far dominate the hazards and thus governing agencies and industries elaborated in GM food firms should enhance public consciousness in the technology to improve universal acceptance of GM foods through openness, education, and research [21]. Africa needs to embrace modern technology in Agriculture to ensure food security for its citizens [22]. However, it is globally agreed that genetically modified crops must be commercialized only after their detailed safety investigation validation is confirmed safe [23]. Therefore, the objective of this review is to study the possible opportunities and challenges of genetically modified crop production in the Ethiopian context taking lessons from the experiences of other countries.

\section{STATUS OF GM CROPS PRODUCTION IN ETHIOPIA}

The continued increase of biotech crops production reveals that agricultural biotechnology will play important impact on agricultural production as far as accepted by farmers everywhere in the world [24]. A new wave of acceptance is evolving in the African continent. Countries such as Malawi, Kenya and Nigeria are on the way from field trial experiment to granting environmental release approvals, while six others: Burkina Faso, Ghana, Ethiopia, Nigeria, Uganda and Swaziland accomplished major progress in touching towards the completion of multi-location field for considering commercial approval of GM crops while Tanzania showed its interest on GM crops [14]. South Africa and Sudan are the most GM crop producers in Africa. In addition to these two countries, Egypt has started producing GM crops [25].

Ethiopia ratified a highly preventive biosafety law in 2009, as Proclamation No.655/2009 and its directives (Directives №.1 to 6/2009) [26]. Whether Ethiopia wants or not, neighboring countries such as Sudan and Kenya have already started producing GM crops and hence GM seeds can be found in the country as far as there is illegal and noncertified exchange of seeds in the borders. However, Ethiopia needs to forward toward revising its biosafety regulations to facilitate active participation of foreign technology providers and local researchers in the biotechnology sector so that it can harness maximum benefits from developments in modern biotechnology [27]. In 2016, the Ethiopian Parliament Amended the GMO Law known as 'A Proclamation to Amend the Biosafety Proclamation, which somehow relaxes the previous, a bit strict GMO policy, by permitting the involvement of Ethiopian researchers initially on non-edible crops [26].

In 2016, at the Ministry of Agriculture's request, the Ministry of Environment, Forest \& Climate (MEFC) approved the importation of $\mathrm{Bt}$ cotton seeds for field trials and research in Ethiopia [17]. As a result, field trials on Bt cotton have been underway at several sites in the cotton-producing areas of Ethiopia [17]. The Bt Cotton crop is on the concluding stage, which will permit the commercialization of the crop. The agricultural biotechnology sector at the Ethiopian Agricultural Research Institute, will probably release the biotech Bt cotton seed varieties to farmers in the coming one or two years [15]. The success of this trial will play pivotal role in the development of other transgenic crops in the country.

Gm crops production may inspire foreign assets and domestic invention in Ethiopia to successfully advance its various interests and increasing competitiveness in agricultural and industrial sectors of the economy [27]. In an effort to improve agricultural productivity and safety, Ethiopia has approved the commercial cultivation of Genetically Modified (GM) cotton and field research on GM maize in 2018 [29, 30]. MEFC approved the environmental release of Bt cotton following two years of confined field trial research by the Ethiopian Institute of Agricultural Research (EIAR). The two cotton hybrids that will be released for commercial cultivation have been tested to ensure they are compatible with Ethiopia's growing conditions [30]. Therefore, assessment of the possible opportunities that can be earned from the application of biotechnology and the potential challenges that may be encountered by the production of GM crops is of utmost importance to Ethiopia if the country is to feed its alarmingly growing population. 


\section{OPPORTUNITIES OF GM CROPS PRODUCTION}

\subsection{Improving Crop Production and Productivity}

Adopting new cultural practices to improve productivity, nutritional quality and pest control has slightly improved production at the cost of jeopardizing sustainable productivity. Biotechnology has played a great role in increasing global crop production and productivity in a sustainable way and also by conserving biodiversity [31]. The influence of GM crops showed an increase in productivity; even though the profitability was higher in developed countries than developing countries [32]. Conventional crop production techniques use a range of chemicals to maximize yields and most of the chemicals have negative impact to the environment. New genetically modified crops are being developed in order to reduce the use of agricultural inputs such as pesticides and artificial fertilizers. This will not only improve profitability but also improve sustainability and reduce adverse effects on the environment and human health [33].

Study revealed that, $37 \%$ reduction in pesticide usage and an increase in yield of over $21 \%$ was obtained by cultivating GM Crops [34], which shows an increase in production and environmental benefit at the same time. Ethiopian economy is dependent on agriculture for food, industrial raw materials such as textile industry and export [35]. However, despite adopting many kinds of production improvement programs, productivity is still very low [36]. This is a critical concept in fostering innovation to transform agriculture sector for more profit and industrialization in Ethiopia.

\subsection{Production Crops for Abiotic Resistance}

Abiotic stresses like frost, drought and increased salinity are a limiting factor to the growth of crops [37]. Most crops are susceptible to elevated salt conditions that are rising due to irrigation and changing climatic conditions $[37,38]$. A plant growing in salt conditions tries to keep salt away from newly emerging meristematic tissue. For example, tomato plants avoid the migration of salt to their reproductive parts by storing the elevated level of salts in their leaves. On the other hand, salt can be managed by transport mechanisms such as the sodium/proton antiport pump that enables a plant to seize sodium ions in the vacuole. One intensely studied example is AtNHX1 antiport. Transgenic tomatoes that over-express the AtNHX1sodium/proton antiport pump from Arabidopsis were able to survive and grow in saline conditions that too salty for ordinary tomatoes [39]. The tomatoes grew, flowered, and produced seeds in a high-salt environment [39]. Interestingly, the GM tomatoes can be safe for human consumption because the altered tomato had high sodium concentrations in the leaves, but not in the fruits, suggesting that the GM crop could be of agricultural values [40].

Another major problem in crop production is climate change and drought. Drought resistant transgenic horticultural crops can also be produced. FRI gene is one of the genes that improve drought resistance in different crop plants [41]. Agrobacterim mediated transformation was used to transfer gene from barley (HVA1) that codes for late embryogenesis into mulberry plants and improved water deficiency stress [42]. GM mulberry with barley Hval under a constitutive promoter (ACTIN1) was reported to enhance drought and salinity stress tolerance [42].

\subsection{Production of Crops for Biotic Resistance}

Scientists are developing genetically engineered crops with new traits like increased resistance to pests, disease or environmental stresses [43]. There are many applications of genetic engineering to develop genetically modified crops that are resistant to pests, diseases and different biological enemies on the field [44]. Ethiopia has recently approved the cultivation of Bt Cotton and started confined field trials of Bt maize [29] which will have great impact to reduce pests and diseases damages and boost production. In Uganda, conventional and transgenic biotechnological approaches are being used in order to produce pest and disease resistant bananas [45]. The main advantages of biotechnology in agriculture sector are producing tolerant crops to biotic and abiotic stresses [46]. Field studies from the insecticidal toxin of the bacterium Bacillus thuringiensis in tomato plant showed resistance to the tobacco hornworm (Manducasexta), the tomato pinworm (Keiferia lycorersicella), tomato fruit worm (Heliothis zea) and the tomato fruit borer (Helicoverpa armigera) [47]. Tomato plants resistant to a root knot nematode have also been produced by inserting a cysteine proteinase inhibitor gene from obtained Taro [48].

Scientists have developed transgenic herbicide resistant crops for the commercial crops. It is possible to transfer these herbicide resistant genes in to plant. This will reduce the cost of production and ensure weed free plant growth and development for effective performance. The emergence of aphid resistance in Chrysanthemum genetically engineered to produce caffeine is of recent significant development [49]. 


\subsection{Biotechnology for Delayed Ripening}

The benefit of biotechnology is not limited to safeguarding plants against stress but also helps to prolong the shelf life of fruits by delaying repining and senescence. The first model plant for fruit ripening were tomatoes [50]. The Flavr Savr tomato is the pioneer GM food to get approval from the Food and Drug Administration (FDA) of America, licensed in 1994 [51]. Ripening causes production of an enzyme called Polygalacturonase (PG) in a gradual increasing level, which is responsible for softening the tomato pectin. However, after genetic engineering, the fruits remained firm for 45 days, which is three times longer than the normal tomatoes which start to wilt after just 15 days. This GM technology was done by suppressing PG production in ripening tomatoes by introducing a reverse-orientation copy of the gene, also known as antisense technology where a reverse copy of the gene is designed to prevent or drastically reduce the formation of $\mathrm{PG}$, resulting in an altered ripening [52]. Ripening in the climacteric fruits can also be delayed by suppressing the production of ethylene hormone required for ripening.

\subsection{Production of Attractive Flowers in Floriculture}

Biotechnology applications have made several efforts to engineer a wide variety of aesthetic traits in the floriculture industry [53] and speed time to flowering [54]. Development of new varieties through traditional technique methods is very difficult or is not an option if varieties are completely sterile, as in orchids [55].

Horticultural crops cultivated for aesthetic values depend on the customers' preferences on the varieties of flower color. For example, most of the roses are either pink or red in color but people in Japan want their flowers to be blue for the expression of love, compassion and pure faith. Classical plant breeding approaches have been trying to produce blue flowers but it was not made possible. A dream became true for many scientists in Japan and Australia when they produced blue roses for the first time using 'dolphinin' gene in genetic transformation [41]. Therefore, it is possible to improve floriculture industry in Ethiopia based on the aesthetic needs of customers.

\subsection{Improvement of Human Nutrition}

Transgenic crops production can improve the quality of food by increasing the nutritional content, promoting stable digestion by lowering glycemic index, improving flavor and taste or reducing those substances in food which traditionally produce allergies $[20,56]$. The amount of pro-vitamin A was increased in tomato fruit by adding a bacterial gene encoding phytoenedesaturase, even though the total amount of carotenoid in the new transgenic tomatoes remained the same [57]. Scientists improved the production of an antioxidant, anthocyanin in tomatoes by using different methods. It was made possible by adding a transcription factor from Arabidopsis thaliana and also possible to increase the levels of isoflavone, which is known for its potential anti cancer properties, by introducing the soybean isoflavone synthase into tomatoes [58]. The GM tomato had increased antioxidants and was promised to protect against cancer and diabetes [59].

In Africa, genetic engineering provides a complementary tool to banana breeders to introduce transgenic bananas with increased pro-vitamin A fruit content in order to improve child nutrition and health [60]. The new GM banana fruit is not only full of vitamins but also rich in iron. Uganda also had showed interest in GM banana [61]. A scientist has got bananas that have up to a 25-fold increase in the level of Provitamin A, which is above the target we need and that technology has already been transferred to Uganda [62].

\subsection{Production of Edible Vaccines, Biopharmaceuticals and Biomolecules}

Scientists are using common plant foods to carry antigens that prime the immune system through producing edible vaccines. Horticultural crops like banana, lettuce and tomatoes can be used for the production of edible vaccines [63]. Plant based vaccines that are cheaper and safe as compared to the traditional vaccines are being adopted by different countries [64, 65]. Molecular pharming has become internationally interesting method for the production of recombinant pharmaceutical proteins in plants [66]. Plants are preferable bioreactors because of their lower cost of production and easy management practices [65]. The first production of a commercially relevant protein, a human growth hormone, was shown in transgenic tobacco plants in 1986 [67].

\section{CHALLENGES OF HORTICULTURAL GM CROPS PRODUCTION}

\subsection{Environmental Effects}

Biosafety requires maintaining an equilibrium among assuring a high level of human health and environmental, 
while at the same time providing a stable regulatory means in the food chain [68]. In addition, some more general concerns include environmental pollution, unintentional gene transfer to wild plants, possible creation of invasive weeds, risk to crop genetic diversity, religious, cultural and ethical concerns, and fright of unknown effects [21].

Gene flow may happen from engineered crops to sexually compatible wild families and to agricultural weeds, there exist gaps of potential effects of gene flow and the effect of specific traits on the performance of the weed or wild families [69]. In Ethiopia, there must exist strong panel of discussions of professionals with clear guidelines, regulation and safety rules to monitor and evaluate introduced GM crops by addressing the following questions: has the product been used as predicted/recommended? Are known effects and side-effects as predicted? Does the product induce unexpected side effects [70]. This helps to maintain GM inputs under the legal tolerance threshold of $0.9 \%$ [71]. The earlier version of the Biosafety Proclamation of Ethiopia, which was stringent, has been revised to support the adoption of the technology [17]. Due to safety fears many countries have refused introduction or production of GM crops. For example, the Scottish Government announced to use the new EU legislation, which prevents GM crops production [18].

As the battle to ensure food and nutritional security of millions of people continues, looking biotechnology as an option is a choice to solve global hanger, but should it be at the expense of nature? This is a growing debate about the potential value of modern biotechnology.

\subsection{Effect on Non Target Organisms (NTOs)}

Genetically modified plants can be hazardous to the health of animals. The transgene which has been inserted in to a target organism to modify its original characteristics for the benefit of human beings may also have a negative effect on other non-target organisms [72]. There are some known effects of biotech crops while others risks are yet to be studied. It was reported that world population of bees is declining rapidly possibly due to, among other factors, use of GM crops [73]. Bluetongue Virus (BTV) is spreading to Northern Europe, a shocking evidence of an 'exotic' vectorborne cattle disease established within new geographical region. This virus has slight understanding of its source, presenting a new and significant risk to animal production [74]. Due to such fears countries such as Italy does not allow commercial cultivation or field trials of any GM plants tested in the country's academic labs or research centers [28].

\subsection{Socio Economic Concerns}

People's attitudes are considered vital factors influencing both the use of biotechnology and its expansion. Concerning future GM non-food products, the majority of experts expect public attitudes to become more positive over the next 10-15 years, while the level of acceptance of GM food products will be unchanged [75]. Opponents of GM technology raises the issue regarding modification in nutritional quality of foods, likely antibiotic resistance from GM crops, potential toxicity, potential allergy and carcinogenicity from GM foods [21]. Coexistence should be permitted for, and appropriate labeling is essential to assurance customers' freedom of choice [75]. Disputes were examined on competitive study of UK and Australia citizens on GMO food acceptance. The acceptance of transgenic foods at government and industry level has not directed to commercial adoption in the UK due to users' confrontation and the influence of EU regulations, whereas Australian governments at federal and state level have progressively embraced GM crops, possibly locking Australia into a GM food and farming trajectory [76]. Biotechnology in over-all, and use of genetic engineering in food production in specific are viewed seriously by the European community and supposed as risky and disparity has been observed between European and US citizens [77].

There exist an immense worry and blame against Bt Cotton from environmentalist and rights groups against biotech industry in general. In India although there are measurable results and implementations of the biotech crops, the country still faces severe oppositions from the wider rages of the rights groups. At some point, the supreme court of India has been involved in the litigations of a case with regards to implementations of biotechnology activities that involved mustard [15]. This is a good lesson to take for African countries like Ethiopia on creating awareness and also participating concerned professionals and rights groups. One challenge of GM crops production is to get certified seed. Growers must purchase GM seeds every year which makes them dependent on GM seed producers and suppliers that charge extra for GM seeds than common seeds. Moreover, seed distribution can be challenging for nations with poor infrastructure. Many countries have planned and applied procedures to address the safety fears of consumers and producers [78] but there is an immense international heterogeneity in labeling regulations [79, 80].

In the last fifteen years, about 40 states have accepted labeling policies, however the characteristics of the policies and their degree of application vary greatly [80, 81, 82]. Most developing countries with leveling policies have failed to implement properly [82]. The slow regulatory capacity is the major challenge that slows down the approval process of 
GM crops in many countries like GM mustard and eggplant in India as well as Bt rice in China [83]. For the past several years, Ethiopia has invested in establishing the legal and regulatory systems, as well as the technical capacity to support and manage the adoption of GM cotton [17].

Among the countries with labeling laws, the only common feature is the quasi-generalized requirement to label products derived from GM crops that are not substantially equivalent to their conventional counterparts [80]. The two broad regulatory approaches for labeling of GM food are: 1) Voluntary labeling which is driven largely by market forces, with no legislative requirements to declare the use of GMOs in food production; and 2) Mandatory labeling which requires declaration of characteristics imparted to a food by the use of gene technology (are they healthy and safe and/or process-related), or use of gene technology itself in food production. Certain countries with mandatory labeling for GM ingredients also have voluntary guidelines for the labeling of non-GM food [80].

\section{CONCLUSION}

The cultivation of genetically engineered plants is increasing from time to time. GM crops have been proven to be solution for the increasing food consumption and industrial demand in many countries. Ethiopian government has permitted commercial cultivation of Genetically Modified (GM) cotton and field research on GM maize in 2018. Which is expected to solve the shortage of industrial raw material to fulfill the high demand of cotton lint for emerging parks and textiles industries. Looking at the option biotechnology was a wise decision to earn more economic benefits. However, introduction of genetically modified crops to the Ethiopian agriculture should include a rational set of governing principles and thoughts to ensure hazardous effect on human, animals and environment, while using the opportunity to use benefits of biotechnology in Ethiopia. The three major standards of performance of a biotech crop; productivity, equitability and sustainability must be assessed in the situation of the Ethiopian crop biodiversity context and agricultural practices taking considerations of thee challenge and opportunities. Moreover, the cultural diversity and socio economic reflection should be taken in to considerations during GM crops introduction.to be acceptable by farmers. People should be aware of the objective of the introduced biotech crops and its management practice. Moreover, public research should be fostered and additional ex ante values and socioeconomic studies should be included and monitoring and evaluation mechanisms need to be set out. The major risks with regarding to the use of genetically engineered edible crops in Ethiopia can be categorized as socio-economic, socio-ethical, health related and biodiversity effects compared with non-edible Bt Cotton. Challenge related to farmers may rely on inputs such as seeds from external source for their agricultural practices making them further susceptible to cost and availability as emerging problem.

\section{CONSENT FOR PUBLICATION}

Not applicable.

\section{CONFLICT OF INTEREST}

The authors declare no conflict of interest, financial or otherwise.

\section{ACKNOWLEDGEMENTS}

Declared none.

\section{REFERENCES}

[1] UN (United Nations, Department of Economic and Social Affairs). Population Division.2017. World Population Prospects: The 2017 Revision, key findings and advance tables Working paper No.ESA/P/WP/248

[2] Mottaleb KA, Mohanty S. Farm size and profitability of rice farming under rising input costs. J Land Use Sci 2015; 10(3): $243-55$. [http://dx.doi.org/10.1080/1747423X.2014.919618]

[3] Ognakossan E, Affognon H, Mutungi C, Sila D, Midingoyi S-K, Owino W. On-farm maize storage systems and rodent postharvest losses in six maize growing agro-ecological zones of Kenya. Food Secur 2016; 8(6): 1-21.

[4] James C. Global status of commercialized biotech/GM crops: Ithaca, NY: International Service for the Acquisition of Agri-Biotech Applications (ISAAA). 2008; ISAAA Brief https://www.isaaa.org/resources/publications/briefs/39/download/isaaa-brief-39-2008.pdf

[5] Blanchfield JR, Lund D, Spiess W. Report on the Food Security Forum. Held in conjunction with the 14th World Congress of Food Science and Technology, Shanghai, China, 19-23 October 2008 
[6] James C. ISAAA Report on global status of biotech/GM crops. International service for the acquisition of Agri-biotech applications. 2014. Available from:http://isaaa.org/resources/publications/briefs/49/pptslides/pdf/B49-Slides-English.pdf

[7] Alexandratos N, Bruinsma J. World agriculture towards 2030/2050: the 2012 revision. ESA working paper No. 12-03. Rome, FAO. 2012 www.fao.org/fileadmin/templates/esa/Global.../world_ag_2030_50_2012_rev.pdf

[8] The future of food and agriculture - Trends and challenges. Rome. 2017 www.fao.org/3/a-i6583e.pdf

[9] Lisen R, Marja-Liisa TB. Land tenure, climate change mitigation and agriculture Mitigation of Climate Change in Agriculture (MICCA) Programme June 2011. Rome: FAO 2011. [http://www.fao.org/climatechange/30353-0c11859e8b0cac7aabe39520498b2df22.pdf]

[10] Borlaug NE. Ending world hunger. The promise of biotechnology and the threat of antiscience zealotry. Plant Physiol 2000; 124(2): 487-90.www.plantphysiol.org [http://dx.doi.org/10.1104/pp.124.2.487] [PMID: 11027697]

[11] Article 2. Use of terms. Montreal, Canada. 2013 https://www.cbd.int/convention/text/default.shtml

[12] Agricultural Biotechnology Research 2017.http:/www.eiar.gov.et/index.php/agricultural-biotechnology-research

[13] van Roekel JS, Damm B, Melchers LS, Hoekema A. Factors influencing transformation frequency of tomato (Lycopersicon esculentum). Plant Cell Rep 1993; 12(11): 644-7.

[http://dx.doi.org/10.1007/BF00232816] [PMID: 24201880]

[14] GM Crops List. Available from 2017. [http://www.isaaa.org/gmapprovaldatabase/cropslist/]

[15] Bob K. Ethiopia to commercialize BT cotton in two years Africa Business Communities News. 2016; 25-11-2016. 12:57:51 http://africabusinesscommunities.com/news/ethiopia-to-commercialize-bt-cotton-in-two-years.html

[16] Ethiopia - Cotton. Addis Ababa. 2017. Available from: https://www.export.gov/article?id=Ethiopia-Cotton

[17] Ethiopia plans to commercialize Bt cotton soon. GAIN Report Number: ET 1637. 2016. Addis Ababa

[18] Directive EU. 2015/412, Article 26b (3). March 2015; Available from: http:/eur-lex.europa.eu/legal content/EN/ALL/? uri=OJ

[19] Consensus document www.icgeb.org/biosafety Guidance for a Fit-for-Purpose Regulatory Framework for GMOs. "International Centre for Genetic Engineering and Biotechnology (ICGEB). 2012.

[20] Wendt J, Izquierdo J. Management of appropriate agricultural biotechnology for small producers: case study - Ecuador. Electron J Biotechnol 2003; 6(1): 1-7.http://www.ejbiotechnology.info/content/vol6/issue1/issues/02/index.html [http://dx.doi.org/10.2225/vol6-issue1-fulltext-i02pdf]

[21] Uzogara SG. The impact of genetic modification of human foods in the 21st century: a review. Biotechnol Adv 2000; $18(3)$ : $179-206$. [http://dx.doi.org/10.1016/S0734-9750(00)00033-1] [PMID: 14538107]

[22] Technology answer to Africa's food security challenge, say scientists EBC; March 9, 2017 http://www.ebc.et/web/ennews/-/technology-answer-to-africa-s-food-security-challenge-say-scientists?inheritRedirect=true

[23] Secretariat of the Convention on Biological Diversity. Secretariat of the Convention of Biological Diversity. 2000 www.cbd.int/convention/convention.shtml

[24] Moussa S. Environmental issues related to genetically modified crops in Africa. NEPAD Agency - African Biosafety Network of Expertise 06 BP 9884. Ouagadougou Burkina Faso. Policy Brief 2012; N03http://www.nepadbiosafety.net/abne

[25] Pretty J. Agricultural sustainability: concepts, principles and evidence. Philos Trans R Soc Lond B Biol Sci 2008; 363(1491): 447-65. [http://dx.doi.org/10.1098/rstb.2007.2163] [PMID: 17652074]

[26] Brook A. Parliament amends GMO law to allow Ethiopian research partnerships Fortune. 2015. May 25, 2015. 16: 785. Available from: http://addisfortune.net/articles/parliament-amends-gmo-law-to-allow-ethiopian-research-partnerships/

[27] Adane A. Toward a workable biosafety system for regulating genetically modified organisms in Ethiopia, GM Crops \& Food 2013; 4(1): 28-35.

[28] Marta P. Bomb attack damages Monsanto research center in Italy Science magazine. Apr. 21, 2017 , 4:15 PM http://www.sciencemag.org/news/2017/04/bomb-attack-damages-monsanto-research-center-italy?utm_campaign=news_weekly_2017-04-28 \&et_rid=299011249\&et_cid=1299697http://www.sciencemag.org/category/europeDOI

[29] Joan C. Ethiopia progresses with GMO crops Alliance for science Cornell University, Mann Library. Ithaca, NY. June 28, 2018 https://allianceforscience.cornell.edu/blog/2018/06/ethiopia-progresses-gmo-crops/

[30] Terefe M. Biosafety issues of genetically modified crops: Addressing the potential risks and the status of GMO crops in Ethiopia. Clon Transgen 2018; 7(2): 164. [http://dx.doi.org/10.4172/2168-9849.1000164]

[31] Remi A. Agricultural Biotechnology: Does it work in Africa? in GMOs for African agriculture: Challenges and opportunities. Workshop proceedings report. Academy of Science of South Africa. July 2010 https:// www.assaf .org.za/ files/ 2010/ 08/ ASSAf- GMO- African Agriculture -2010- Part-1.pdf

[32] Hall C, Knight B, Ringrose S, Knox O. What have been the farm economic impacts of the global cultivation of GM crops? 2013. http:// www.environmentalevidence.org/wp-content/uploads/2014/07/CEE11-002.pdf 
[33] Baulcombe D, Dunwell J, Jones J, Pickett J, Puigdomenech P. GM science update: a report to the Council for Science and Technology Council for Science and Technology, London. 2013. Available from: https:// www.gov.uk/ government/ uploads/ system/ uploads/ attachment_data/ file/ 292174/ cst-14-634a-gm-science-update.pdf

[34] Klümper W, Qaim M. A meta-analysis of the impacts of genetically modified crops. PLoS One 2014; 9(11): e111629. [http://dx.doi.org/10.1371/journal.pone.0111629] [PMID: 25365303]

[35] Mafa C, Bezabih E, Demese C. Ethiopia’s Agriculture Sector Policy and Investment Framework (2010-2020). External Mid-term Review. 2015 http://www.agri-learning-ethiopia.org/wp-content/uploads/2015/10/Agriculture-Policy-MTR_FINAL.pdf

[36] African Economic Outlook, Ethiopia, 2012 www.africaneconomicoutlook.org

[37] Foolad MR. Current Status of Breeding Tomatoes for Salt and Drought Tolerance. Advances in Molecular Breeding Toward Drought and Salt Tolerant Crops 2007; pp. 669-700. [http://dx.doi.org/10.1007/978-1-4020-5578-2_27]

[38] Dorothea B, Ramanjulu S. Drought and Salt Tolerance in Plants. Crit Rev Plant Sci 2005; 24: 23-58. [http://dx.doi.org/10.1080/07352680590910410]

[39] Apse MP, Sottosanto JB, Blumwald E. Vacuolar cation/H+ exchange, ion homeostasis, and leaf development are altered in a T-DNA insertional mutant of AtNHX1, the Arabidopsis vacuolar Na+/H+ antiporter. Plant J 2003; 36(2): 229-39. [http://dx.doi.org/10.1046/j.1365-313X.2003.01871.x] [PMID: 14535887]

[40] Zhang HX, Blumwald E. Transgenic salt-tolerant tomato plants accumulate salt in foliage but not in fruit. Nat Biotechnol 2001; 19(8): 765-8. [http://dx.doi.org/10.1038/90824] [PMID: 11479571]

[41] Chandler SF, Tanaka Y. Transgenic research in floricultural crops.In Genetic Engineering of Horticultural Crops. 2018; pp. 121-36. [http://dx.doi.org/10.1016/B978-0-12-810439-2.00006-4]

[42] Checker VG, Chhibbar AK, Khurana P. Stress-inducible expression of barley Hval gene in transgenic mulberry displays enhanced tolerance against drought, salinity and cold stress. Transgenic Res 2012; 21(5): 939-57. [http://dx.doi.org/10.1007/s11248-011-9577-8] [PMID: 22160463]

[43] Nowicki M, Elżbieta UK, Majid RF. Late blight of tomato.Late blight of tomato In:Translational Genomics for Crop Breeding: Volume ", Biotic Stress. 2013. John Wiley \& Sons, Inc.: 241-265 [http://dx.doi.org/10.1002/9781118728475.ch13]

[44] Kikulwe ME, Nowakunda K, Byabachwezi MS, et al. Development and dissemination of improved banana cultivars and management practices in Uganda and Tanzania. Washington, D.CW.K., International Food Policy Research Institute 2007. Research report no. 155 ch. 4

[45] Kikulwe E, Justus W, José FZ. Introducing a Genetically Modified Banana in Uganda Social Benefits, Costs, and Consumer Perceptions. International Food Policy Research Institute NY. 2008; Available from: http:// citeseerx. ist. psu. edu/viewdoc/ download?doi= 10.1.1.540 $.9986 \&$ rep $=$ rep $1 \&$ type $=$ pdf

[46] Askari-Khorasgani O, Pessarakli M. Safety assessment of genetically modified crops for yield increase and resistance to both biotic and abiotic stresses and their impact on human and environment. Adv Plants Agric Res 2018; 8(2): 109-12. [http://dx.doi.org/10.15406/apar.2018.08.00300]

[47] Kumar H. Tomato expressing Cry1A(b) insecticidal protein from Bacillus thuringiensis protected against tomato fruit borer, Helicoverpaarmigera (Hübner) (Lepidoptera: Noctuidae) damage in the laboratory, greenhouse and field. Crop Prot 2004; 23(2): 135-9. [http://dx.doi.org/10.1016/j.cropro.2003.08.006]

[48] Chan YL, Yang AH, Chen JT, Yeh KW, Chan MT. Heterologous expression of taro cystatin protects transgenic tomato against Meloidogyne incognita infection by means of interfering sex determination and suppressing gall formation. Plant Cell Rep 2010; 29(3): 231-8. [http://dx.doi.org/10.1007/s00299-009-0815-y] [PMID: 20054551]

[49] Kim YS, Lim S, Kang KK, Lee YJ, Choi YH, Sano H. Resistance against beet armyworms and cotton aphids in caffeine producing transgenic Chrysanthemum. Plant Biotechnol 2011; 28: 393-5. [http://dx.doi.org/10.5511/plantbiotechnology.11.0510a]

[50] Alexander L, Grierson D. Ethylene biosynthesis and action in tomato: A model for climacteric fruit ripening. J Exp Bot 2002; 53(377): 2039-55.

[http://dx.doi.org/10.1093/jxb/erf072] [PMID: 12324528]

[51] 1994. FDA. Consumer Letter (September 1994): First Biotech Tomato Marketed ^ GEO-PIE Project - Cornell University

[52] Buncombe A. India's new delicacy: a 45-day-old tomato - Asia, World. London: The Independent 2010; -02-09 www. independent. co.uk news/world/ asia/indias -new-delicacy -a-45-day- old-tomato- 1893333.html

[53] Clark DG, Loucas H, Shibuya K, Underwood B, Barry K, Jandrew J. Biotechnology of Floriculture Crops - Scientific Questions and Real World Answers. Plant Biotechnology 2002 and Beyond 2003; pp. Springer, Dordrecht337-42.

[54] Jiang L, Yuan L, Xia M, Makaroff CA. Proper levels of the Arabidopsis cohesion establishment factor CTF7 are essential for embryo and megagametophyte, but not endosperm, development. Plant Physiol 2010; 154(2): 820-32. [http://dx.doi.org/10.1104/pp.110.157560] [PMID: 20671110]

[55] Da Silva JA, Chin DP, Van PT, Mii M. Transgenic orchids. Sci Hortic (Amsterdam) 2011; 130: 673-80. [http://dx.doi.org/10.1016/j.scienta.2011.08.025] 
[56] James C. Global Review of Commercialized Transgenic Crops: ISAAA Briefs No 23. NY, USA: ISAAA Ithaca 2001.http:// www.isaaa .org/pub lications/ briefs/ Brief_23.html

[57] Paroda R. Biosafety Regulations of Asia-Pacific Countries FAO, APCoAB. APAARI 2008.

[58] Nayar A. Grants aim to fight malnutrition. Nature 2011. [http://dx.doi.org/10.1038/news.2011.233]

[59] Mike P. What the papers say. BBC News 2008.

[60] Ortiz R, Swennen R. From crossbreeding to biotechnology-facilitated improvement of banana and plantain. Biotechnol Adv 2014; 32(1): 158-69. [http://dx.doi.org/10.1016/j.biotechadv.2013.09.010] [PMID: 24091289]

[61] Giulio S. Bananas to help boost iron levels of pregnant mums in India BC News 10, 2012 07:32:38) Available from: www.abc .net.au/ news/2012- 03-09/ aussie-scientists -provide

[62] Bronwyn H. India goes bananas for GM fruit 2012.www.abc.net.au/news/2012-03-09/aussie-scientists-provide-india-with-iron-rich-bananas

[63] Ankita M, Sachin MV, Srinivasan M, Subathra CD. Banana as edible vaccine against hepatitis-B: A theoretical model. J Immunol Endocr Metab Agents Med Chem 2016; 16(2): 129-33.

[http://dx.doi.org/10.2174/1871522216666160720101426]

[64] Horn ME, Woodard SL, Howard JA. Plant molecular farming: systems and products. Plant Cell Rep 2004; 22 (10): 711-20. [http://dx.doi.org/10.1007/s00299-004-0767-1] [PMID: 14997337]

[65] Giddings G, Allison G, Brooks D, Carter A. Transgenic plants as factories for biopharmaceuticals. Nat Biotechnol 2000; $18(11)$ : 1151-5. [http://dx.doi.org/10.1038/81132] [PMID: 11062432]

[66] Fischer R, Stoger E, Schillberg S, Christou P, Twyman RM. Plant-based production of biopharmaceuticals. Curr Opin Plant Biol 2004; 7(2): $152-8$. [http://dx.doi.org/10.1016/j.pbi.2004.01.007] [PMID: 15003215]

[67] Leite A, Kemper L, Da Silva MJ, Luchessi AD. Expression of correctly processed human growth hormone in seeds of transgenic tobacco plants. Mol Breed 2000; 6(1): 47-53. [http://dx.doi.org/10.1023/A:1009648532210]

[68] Robert P, Guillermo H. Food Safety: State-of-Play, Current and future challenges. In-depth analysis. 2014; IP/A/ENVI/2014-11.PE.536.287. Available from: http://www.europarl.europa.eu/studies

[69] Clark SJ, Rothery P, Perry JN. Farm Scale Evaluations of spring-sown genetically modified herbicide-tolerant crops: a statistical assessment. Proc Biol Sci 2006; 273(1583): 237-43. [http://dx.doi.org/10.1098/rspb.2005.3282] [PMID: 16555793]

[70] EFSA Panel on Genetically Modified Organisms (GMO); Scientific Opinion on Guidance for risk assessment of food and feed from genetically modified plants EFSA Journal 2011; 9(5)2011;2150

[71] Devos Y, Demont M, Dillen K, Reheul D, Kaiser M, Sanvido O. Coexistence of genetically modified (GM) and non-GM crops in the European Union: A review. Agron Sustain Dev 2009; 29(1): 11-30. [http://dx.doi.org/10.1051/agro:2008051]

[72] Censored, Center for Environmental Risk Assessment. GM Crop Database: Tomato. 2007; Available from: http://www.projectcensored.org/censored_2007/index.htm

[73] Holmes B. Altered animals: Creatures with bonus features. New Sci 2010; 7(July)http://www.projectcensored.org/censored_2007/index.htm

[74] Jones KE, Patel NG, Levy MA, et al. Global trends in emerging infectious diseases. Nature 2008; 451(7181): 990-3. [http://dx.doi.org/10.1038/nature06536] [PMID: 18288193]

[75] Genetically modified plants and foods Challenges and future issues in Europe Final report Berlin. 2009; Available from: http://www.eptanetwork.org/EPTA/projects.php?pid=150

[76] Dibden J, Gibbs D, Cocklin C. Framing GM crops as a food security solution. J Rural Stud 2013; $29: 59-70$. [http://dx.doi.org/10.1016/j.jrurstud.2011.11.001]

[77] Sinemus K. Communicating science, technical, ethical and social aspects related to GMOs: in 1st Global Conference on GMO Analysis. 2008. Villa Erba, Como, Italy 24-27 June 2008. Available from: http://file.cbd.int/database/attachment/?id=2330

[78] Beckmann V, Soregaroli C, Wesselern J. Co-existence rules and regulations in the European Union. Am J Agric Econ 2006; 88(5): 1193-9. [http://dx.doi.org/10.1111/j.1467-8276.2006.00932.x]

[79] Moghissi AA, Jaeger LM, Shafei D, Bloom LL. Regulatory science requirements of labeling of genetically modified food. Crit Rev Biotechnol 2018; 38(3): 386-93. [http://dx.doi.org/10.1080/07388551.2017.1356804] [PMID: 29041813]

[80] Gruère GP, Rao SR. A review of international labeling policies of genetically modified food to evaluate India's proposed rule. AgBioForum 2007; 10(1): 51-64.

[81] Phillips PW, McNeill H. Labeling for GM foods: Theory and practice. AgBioForum 2000; 3(4): $219-24$. 
[82] Haigh M. Handbook on the labeling of genetically modified foods, ingredients and additives. Surrey, UK: Leatherhead Food International 2004

[83] Pingali P. Will The Gene Revolution Reach the Poor? Lessons from the green revolution. Paper presented at the Wageningen University. Mansholt. Wageningen, The Netherlands

\section{(C) 2018 Gebretsadik and Kiflu.}

This is an open access article distributed under the terms of the Creative Commons Attribution 4.0 International Public License (CC-BY 4.0), a copy of which is available at: (https://creativecommons.org/licenses/by/4.0/legalcode). This license permits unrestricted use, distribution, and reproduction in any medium, provided the original author and source are credited. 